\title{
CrimRxiv
}

\section{Explaining Criminal \\ Careers: Implications for \\ Justice Policy}

John F. MacLeod, Peter Grove, David Farrington

Published on: Jul 01, 2012

DOI: 10.21428/cb6ab371.4a710b45

License: Creative Commons Attribution 4.0 International License (CC-BY 4.0). 
